DOI 10.5216/ia.v46i2.67782

\title{
A ESCOLARIZAÇÃO DOS IMIGRANTES ALEMÃES EM JUIZ DE FORA: PROJETOS EM DISPUTA ENTRE OS SÉCULOS XIX E XX
}

\author{
Paloma Rezende de Oliveira \\ Universidade do Estado de Minas Gerais (UEMG), Carangola, Minas Gerais, Brasil
}

\begin{abstract}
Resumo: Em meados do século XIX, o Brasil recebeu grupos de imigrantes de diferentes etnias. Esse processo foi resultado de uma política governamental que atraiu para Juiz de Fora (MG): alemães, italianos, árabes e portugueses. A fim de compreender os impactos da imigração na organização dos processos educativos e sua configuração no município, buscou-se levantar e analisar as fontes do Arquivo da Paróquia de Nossa Senhora da Glória, dando enfoque à escola alemã. Os resultados demonstraram as disputas existentes entre os colonos e os padres redentoristas pelo controle dos bens e do programa de ensino dessa instituição, no que diz respeito ao ensino da língua e da religião de origem.
\end{abstract}

PALAVRAS-CHAVE: Alemães. Imigração. Escolarização. Infância. Secularização.

\section{INTRODUÇÃO}

A trajetória dos grupos germânicos que vieram para a Cidade do Paraibuna, na Província de Minas Gerais, a partir de 1858, esteve atrelada à política imperial de incentivo à vinda de imigrantes para trabalhar no Brasil, em especial na província do Rio de Janeiro.

loti (2010) destaca algumas legislações promulgadas durante o Império a fim de promover a colonização nacional e estrangeira, dentre as quais daremos destaque à lei 514, de 28 de outubro de 1848, que concedeu terras devolutas às províncias, e à Lei de Terras de 1850, que criou a Repartição Geral das Terras Públicas e foi regulamentada pelo decreto 1318, de 30 de janeiro de 1854, que definiu terras devolutas, abolindo a gratuidade de lotes aos colonos e estabelecendo a compra como único título de posse. Essa mudança, segundo a autora, gerou o desenvolvimento de colônias particulares, como as colônias de parceria e os núcleos coloniais. Além disso, após certo tempo de residência, era conferida a naturalização de direito e a dispensa do serviço militar aos colonos proprietários de terras.

A imigração em Juiz de Fora, por sua vez, antecedeu sua própria configuração política como cidade. Como aponta Costa (2011), a vila de Santo Antônio do Paraibuna surgiu no início do século XIX devido à ocupação por famílias vindas da região aurífera (Ouro Preto e Mariana) e, posteriormente, da região das Vertentes (Barbacena e São João Del-Rei). Emancipou-se de Barbacena em 1850, passando a receber o nome de município de Santo Antônio do Paraibuna. Em 1856, foi elevada a Cidade do Paraibuna e sete anos após o primeiro grupo de imigrantes germânicos se estabelecerem na cidade, em 1885, foi que recebeu o nome de Juiz de Fora. 
Destaca-se nesse processo de fundação da cidade o nome de Heinrich Wilhelm Ferdinand Halfeld que, segundo Stheling (1979), foi um tenente engenheiro vindo da Alemanha, em 1825, para integrar o "Corpo de Tropas Estrangeiras" do Exército Brasileiro, sendo nomeado "Engenheiro da Província de Minas Gerais".

A Cidade do Paraibuna recebeu um número significativo de imigrantes germânicos' ${ }^{1}$, que vieram trabalhar na construção da estrada que ligaria a Província de Minas a do Rio de Janeiro. De acordo com Oliveira (2016), eles foram contratados pela Companhia União Indústria ${ }^{2}$, recém-criada por Mariano Procópio Ferreira Lage ${ }^{3}$. Este homem público conseguiu autorização do Imperador D. Pedro II para a construção e concessão de 50 anos para explorar a estrada, inaugurada em 23 de junho de 1861. Em decorrência de sua relevância para a estruturação da cidade, hoje é reconhecida como patrimônio cultural de Juiz de Fora.

Com base nas informações apresentadas no Almanaque História de Juiz de Fora sobre o contrato assinado entre a Companhia União Indústria em Hamburgo, podemos obter indícios sobre os ofícios e a origem de alguns dos primeiros artífices alemães que habitaram a cidade: o mestre de seges, Heinrich Griese, de Preetz, Holstein; os ferreiros: Pedro Schubert Sênior, João Ulrico Schiess e Balthazar Espeschit, sendo este último do Grão-Ducado de Essen, vale do Rur; os seleiros, João Stiegert e Baltazar Weydt; e o folheiro, Frederico Peters. ${ }^{4}$

Se somado o número de trabalhadores independentes e de famílias chega-se a mais de mil imigrantes ${ }^{5}$, em 1858 , o que corresponde a pouco mais da metade pretendida pela Companhia. A mediação entre a empresa e os artífices era feita por Eschels que, na propaganda realizada na Europa sobre a cidade de Juiz de Fora para atrair os alemães, omitiu o fato de que a cidade não possuía infraestrutura, tendo os imigrantes que se instalarem em um acampamento. Segundo Martins (2019), a instalação definitiva das colônias se deu em cerca de cinco anos: a Colônia Agrícola Dom Pedro II (que deu origem ao bairro São Pedro), a Colônia de Baixo (região do bairro Borboleta) e o Villagem ou Colônia do Meio (região que corresponde ao bairro Fábrica).

Na edição especial do Tribuna de Minas (2000, p. 4), podemos localizar algumas das primeiras famílias de imigrantes que construíram suas casas reproduzindo a arquitetura de suas vilas natais, entre elas as de sobrenome: Kelmer, Lembke, Muller, Dilly, Weitzel, Kirchmayer, Surerus, Wolf, entre outros. Nesse grupo, outros ofícios podem ser destacados, como produtores de cerveja e comerciantes. Cabe ressaltar que desde a chegada dos colonos até o ano de 1912, 58\% das empresas instaladas no município pertenciam a imigrantes luteranos.

As abordagens que tratam da questão imigratória no Brasil, como as de Kreutz (2013), Seyferth (2011), Renk e Maschio (2020) e Santos (2012), evidenciam a permanência entre os imigrantes de relações sociais relacionadas à cultura e organização social de origem, dentre as quais a preservação da língua materna, que é tida como essencial a sua identidade.

Um dos aspectos evidenciados, especialmente por Seyferth, é a ação das diversas instituições comunitárias na preservação e divulgação desses valores étnicos, entre as quais se destaca a escola alemã como essencial à manutenção das 
OLIVEIRA, P. R. de.

características da cultura de origem, considerada a responsável pela preservação do idioma.

\begin{abstract}
As instituições comunitárias formadas praticamente desde o início da colonização (...) tiveram maior notoriedade como elementos de diferenciação cultural (...). Atribui-se maior importância à escola alemã, considerada indispensável para perpetuar o ensino da língua materna (...) (SEYFERTH, 2011, p. 54).
\end{abstract}

A questão da língua e também a expressão religiosa foram pontos tênues na relação entre católicos e protestantes no contexto de Juiz de Fora. Como o catolicismo era a religião do Império, os luteranos não podiam, por exemplo, ser enterrados em cemitérios católicos, embora os cemitérios públicos existissem desde 1828. Desse modo, com a inauguração da Igreja da Colônia, no Morro da Gratidão, em dois de julho de 1878, então sob a denominação de Igreja de Nossa Senhora da Glória, foi criado um anexo para sepultar os protestantes, o qual foi construído com recursos da "Liga Católica Alemã". ${ }^{6}$

Para além das relações entre os imigrantes alemães e a população brasileira enfatizadas por Seyferth (1996), que utiliza a etnia como uma categoria de análise em educação a fim de compreender de que forma o processo educacional e escolar tem se desenvolvido em relação à diferenciação cultural, temos que considerar que há uma multiplicidade de culturas que se entrelaçam e perpassam aspectos identitários, religiosos, econômicos e políticos. Eles revelam relações hierárquicas e de poder até mesmo dentro dos próprios grupos étnicos.

Com isso, pretendemos situar as experiências de escolarização dos imigrantes alemães em Juiz de Fora, partindo do entendimento de Faria Filho (2020) de que a escola é um lugar de cultura e de constantes disputas. Com base nessa perspectiva, buscamos indicar as diferentes culturas escolares criadas pelos e para os habitantes da colônia alemã, no contexto local, e identificar as particularidades e similaridades destas ações, medidas e projetos em relação às iniciativas relacionadas aos processos escolares situados predominantemente na região sul do país.

Portanto, essas iniciativas não podem ser vistas como dissociadas de um contexto mais amplo, haja vista se compararmos o contexto de Juiz de Fora com o do sul do país, já analisado por Santos (2012). É possível perceber que as escolas criadas representaram tanto uma iniciativa das famílias nas comunidades alemãs como um investimento de caráter comercial feito com a subvenção financeira por parte da companhia colonizadora.

A preocupação com a fundação de escolas pelas comunidades de imigrantes alemães em diversas regiões do país foi um aspecto que se destacou como prioridade na colonização alemã, por isso, embora a análise se detenha nas relações entre sujeitos que viviam em Juiz de Fora, não se perde de vista sua relação com o contexto nacional.

Como enfatiza Carvalho (2013), o recorte delimita a temática em função das particularidades, mas isso não reduz os aspectos relativos às relações sociais, pois cada detalhe assume um significado próprio e, portanto, distinto dos estudos históricoeducacionais macroestruturais que focam nas semelhanças.

A análise de fontes documentais variadas, levantadas no Arquivo da Paróquia de Nossa Senhora da Glória, situado no município, revelou alguns vestígios deixados 
pelos padres redentoristas, tais como: recortes de notícias de jornais, livros de atas e balancetes da Sociedade Propagadora do Ensino Primário, cartas pastorais, livro de tombo, fotografias. Esses elementos ajudaram a compreender os impactos da imigração na organização dos processos educativos e sua configuração no município, bem como sua relação com o contexto social mais amplo, ou seja, o nacional.

Esta pesquisa de caráter documental sinalizou para outras possibilidades de utilização de publicações, não estritamente marcadas por um viés educativo. $O$ que, segundo os escritos sobre os usos e destinos dos impressos em História da Educação de Magaldi e Xavier (2008, p. 10), viabiliza a "(...) a captação de debates e ações no campo educacional, no momento mesmo em que se processavam e pela possibilidade de promover o acesso do pesquisador a diferentes vozes e diferentes diagnósticos acerca das questões educacionais".

Nesse sentido, os resultados indicaram as disputas existentes entre os colonos e os padres redentoristas pelo controle dos bens e do programa de ensino dessa instituição, no que diz respeito ao ensino da língua e da religião de origem.

Cabe ressaltar que as fontes consultadas constituem o acervo de um arquivo paroquial, expressando memórias produzidas e divulgadas pelos católicos holandeses sob as mais diferentes formas de publicação. Logo, foi preciso atentar para o tipo de formação escolar que era projetada e os esforços investidos por este grupo em conquistar novos adeptos à religião católica, sendo necessário questionar as fontes e os significados que buscavam produzir, especialmente sobre os imigrantes alemães e sua instrução.

\section{A ASSOCIAÇÃO DO CULTO CATÓLICO E SUA ATUAÇÃO EM JUIZ DE FORA}

No final do século XIX, os redentoristas holandeses ${ }^{7}$ se instalaram em Juiz de Fora, logo entrando em conflito com os membros da colônia alemã. De acordo com Azzi (2000), em 26 de abril de 1894, três padres e três religiosos leigos chegaram a Juiz de Fora, sendo fundada a primeira casa dos padres redentoristas da província holandesa.

De acordo com Oliveira (2012), as tensões originaram-se de duas questões de natureza diversa, que foram: a disputa pelo controle dos patrimônios e as divergências étnicas e educacionais. A questão dos patrimônios antecedeu a chegada da congregação, sendo uma repercussão dos atritos surgidos durante o segundo reinado e que se intensificou com a afirmação do movimento da reforma católica. Além da questão dos patrimônios, a controvérsia entre os religiosos holandeses e os colonos envolvia também a questão de nacionalidade. Os alemães queriam preservar seu idioma de origem, suas expressões de fé, contudo não encontravam a compreensão devida por parte dos padres que assumiram o Curato da Glória em 1893, passando a reivindicar a posse de todos os chamados patrimônios eclesiásticos.

Ainda segundo a autora, isso se deu em resposta à secularização do Estado. $\mathrm{O}$ bispo de Mariana exigiu a posse de todos os bens, mesmo os pertencentes às irmandades e ordens terceiras. Muitas se recusaram a abrir mão dos direitos conferidos pelo governo imperial, como foi o caso da associação do Culto Católico de Juiz de Fora, uma instituição comunitária que administrava, entre outros bens, aqueles doados em 
OLIVEIRA, P. R. de.

1885 pela Companhia União Indústria aos colonos alemães que viviam na Colônia Dom Pedro II, situada nas proximidades da Estação denominada Mariano Procópio.

O Vigário Geral, Matias Tulkens, veio ocupar a vaga do capelão alemão, Adolpho Januska, que havia falecido, e exigiu, sob ordem do bispo Dom Silvério, que os estatutos da associação do Culto Católico declarassem formalmente que estariam sujeitos "à autoridade eclesiástica" (LIVRO DE TOMBO, 1885, p. 8).

Isso provocou a reação dos membros dirigentes da associação que apelaram para o documento de escritura datado de 1885, em que constava a doação do terreno onde estavam situadas as escolas do sexo feminino e masculino, nas proximidades do estabelecimento onde funcionou a Escola Agrícola da Companhia União Indústria.

De acordo com Martins (2019, p. 31), estas escolas doadas ao Culto Católico funcionaram desde o ano da doação até 1893, ano da morte do professor, "padre Januschka". No mesmo ano, devido aos embates entre os colonos e os padres católicos, a comissão do Culto Católico ressaltou que não admitiria a intromissão eclesiástica em negócios pertencentes ao Culto Católico da Colônia Dom Pedro II, o que resultou no fechamento das escolas, reabertas em 1900, sob a direção das irmãs de Santa Catharina.

De acordo com Oliveira (2009), elas continuaram sendo mantidas pelo Culto Católico que garantia a gratuidade para os filhos e filhas dos colonos católicos e protestantes. No mesmo ano, foi criado um estatuto com o objetivo de continuar a custear as escolas para os filhos dos associados e demais crianças do bairro Mariano Procópio, prevendo o ensino das primeiras letras, da doutrina cristã e de trabalhos domésticos, sendo feita a seguinte divisão: duas classes para as crianças que só falavam português e duas classes para as que só falavam alemão.

Foram ainda construídos dois novos prédios onde funcionariam as escolas paroquiais: a Escola da Glória ou Escola dos Pobres, para as meninas, e o Salão de São Geraldo, para os meninos.

Em 1907, um novo embate foi gerado quando o Culto Católico criou uma comissão ${ }^{8}$ de caráter leigo para ajudar o cura a administrar as escolas. Não aceitando a situação, o padre pediu à população que retirasse as crianças da escola administrada pelos colonos, sob a alegação de que a diretoria da Associação tinha afinidade com os princípios protestantes. Com essa proibição, os alunos católicos passariam a frequentar as escolas das Irmãs de Santa Catharina, administradas pelo cura que também presidiria a Sociedade Propagadora do Ensino Primário. Em 1908, a entidade especificou os fins do ensino primário em seus estatutos, a fim de garantir a distinção em relação às escolas administradas pelo Culto Católico. Naquele mesmo ano, a Sociedade contava com três escolas: de São Geraldo, criada em 1906, a escola noturna da Tapera, para meninos, e a Escola de Santa Catharina, em construção (LIVRO DO TOMBO, 1894-1925, p. 99).

A diferença no programa de ensino pode ser percebida na medida em que enquanto as escolas sob o controle paroquial e direção das irmãs católicas mantinham a separação entre os sexos, o ensino exclusivamente da língua portuguesa, a instrução nas ciências humanas e na fé católica; a escola alemã tinha caráter misto, o ensino era bilíngue (português e alemão), além de contar com aulas de aritmética, geografia, religião e trabalhos de agulha.

Frente a essa diferenciação no programa e nas práticas de ensino, o cura da Igreja de Nossa Senhora da Glória mantinha suas críticas em relação à iniciativa do Culto Católico, alegando que as escolas desta associação eram contrárias à intenção de seus 
doadores de manter e propagar a fé católica. O padre Wiegant reivindicava então o direito da autoridade eclesiástica em inspecionar o ensino, escolher os livros didáticos e o pessoal docente, o que foi rechaçado pela comissão do culto, que não aceitou essa interferência.

A disputa foi então levada ao fórum local, em 1911, para dar início ao processo de posse e manutenção dos bens, sendo decidido no tribunal de segunda instância a favor da Congregação holandesa. Os meninos permaneceram na Escola localizada no salão de São Geraldo, criada em 1906, localizada em frente à Igreja de Nossa Senhora da Glória, enquanto as meninas passaram a estudar na Escola das Irmãs de Santa Catharina, já no novo prédio construído em estilo alemão.

As escolas paroquiais, segundo Martins (2019), remontam a uma forma antiga de educação cristã que deu origem às universidades medievais e não foram criadas somente no contexto juiz-forano, estando presentes também no Rio de Janeiro, nos séculos XIX e tendo seu número ampliado no século XX. O autor atribui essa iniciativa ao "Concílio Plenário Latino Americano", de 1899, que buscou estimular a difusão dessas escolas de ensino primário nas paróquias para combater a escola estatal, protestante, maçônica, dentre outras:

Esse Concílio, convocado em Roma por Leão XIII, tentou organizar a hierarquia católica latino-americana em torno de um projeto ultramontano. Os documentos desse Concílio se tornaram constituição eclesiástica da Igreja latino-americana. No Brasil, foram substituídas em 1915 por Concílios regionais da Bahia e do Rio de Janeiro (MARTINS, 2019, p. 349).

No caso de Juiz de Fora, a expansão do ensino primário confessional não se limitou às escolas paroquiais. Em 1928, as autoridades eclesiásticas buscaram ampliar sua influência também sobre as escolas estaduais, que se instalaram nas mediações do Curato da Glória. Isso porque o aluguel dos prédios pertencentes à paróquia para funcionamento dessas escolas se dava sob a exigência e condição de que as professoras fossem católicas, que fosse dada diariamente uma aula de catecismo, que um sacerdote pudesse dar pelo menos uma aula por semana e que as ornamentações religiosas não fossem retiradas das salas, podendo a autoridade eclesiástica suspender o aluguel se julgasse necessário (CONTRATO de funcionamento para a escola de São José, 20 jul. 1928).

Em documento remetido à Cúria Arquidiocesana pelo então capelão Vicente Zey, em 1925, podemos também constatar essa influência: "Como é dada a instrução religiosa nas escolas e grupos escolares? Aula semanal de catecismo em todas, menos no grupo escolar, estando grande parte das crianças em escolas paroquiais" (LIVRO DO TOMBO, 1925, p. 173).

Com isso, podemos perceber que a escola primária no interior das sociedades se constituiu como um espaço de construção de identidades e disputas. Nesse sentido, é importante compreender como os alemães conceberam e produziram seus modos de manter traços de sua cultura, e de construir e reafirmar sua identidade em solo brasileiro, 
OLIVEIRA, P. R. de.

frente ao projeto hegemônico das congregações religiosas de ampliação da escolarização primária católica como reação à secularização.

Como indicaram Kreutz (2013), Renk e Maschio (2020), a articulação entre a educação (escola) e a Igreja (religião) foi um dado característico de algumas comunidades. Contudo, precisamos atentar para o fato de que nem sempre esta relação apresentada pelos autores deu-se de modo harmonioso, pois nem sempre os interesses das congregações eram comuns aos dos colonos.

Trazer à tona esta pesquisa sobre a temática, no contexto mineiro, abre possibilidades de estudos comparativos entre as diferentes regiões do país, uma vez que a produção historiográfica, nas últimas décadas, vem colocando em evidência as singularidades e regularidades das instituições e das práticas escolares no contexto de imigração, lançando luz sobre os distintos aspectos desse processo de escolarização, tendo como foco a região sul do país.

Ao falar das escolas da imigração alemã no Brasil devemos ter em mente que elas não eram todas iguais. No caso de Juiz de Fora, a escola aceitava alunos católicos e luteranos, bem como os não pertencentes à imigração alemã. A homogeneidade étnica não era uma característica tão presente como nas escolas do sul do país.

Ainda assim, identificamos pontos comuns em relação ao que foi apontado por Kreutz (2013, p. 22262), como o mais característico do processo escolar da imigração alemã do Rio Grande do Sul, que eram as "escolas étnico-comunitárias de núcleos rurais", assumidas pelas respectivas comunidades de imigrantes, porém vinculadas à coordenação das confissões religiosas.

No entanto, essa administração apresentava interesses conflitantes com os dos imigrantes, pois uma outra característica dos alemães, identificada por Kreutz (2013), é a de buscar expressar sua cidadania por meio da participação comunitária, da sociedade civil e do comprometimento com o local/regional. No caso de Juiz de Fora, eles foram grandes responsáveis pelo desenvolvimento agrícola, comercial e industrial da cidade, antes da chegada dos religiosos holandeses que, logo ao chegarem, buscaram maior controle sobre as associações civis e a instrução escolar, não se mostrando tolerantes à autonomia civil'?

A prioridade dada à escola é apontada por Santos (2012, p. 544), em sua análise sobre a imigração alemã, no contexto do sul do país, como "uma das características típicas das comunidades de imigrantes alemães". Contudo, no contexto juiz-forano, a escola dos colonos encontrou obstáculos, após a chegada dos redentoristas, para conjugar o ensino de língua alemã com o ensino da língua pátria. Segundo Kreutz (2013), enquanto aquela era "importante para eles por seu significado simbólico", esta era "considerada importante para a inserção dos alunos na realidade nacional mais ampla". Isso porque as manifestações religiosas e o ensino nas escolas paroquiais passaram a ser ministrados em língua portuguesa.

A "QUESTÃO ALEMÃ" (1878 A 1917) E OS EMBATES E DISPUTAS ENTRE A EDUCAÇÃO "LEIGA" E RELIGIOSA NO INÍCIO DA REPÚBLICA

A "questão alemã", que se arrastou de 1878 a 1917, no município de Juiz de Fora, foi delimitada na documentação dos padres redentoristas holandeses pelos embates e problemas surgidos com a divisão do cemitério entre católicos e luteranos, 
em 1878, a disputa entre redentoristas e colonos alemães pela posse dos terrenos concedidos à Colônia de Dom Pedro II, em 1885, e a disputa pela instrução dos colonos, a partir de 1894, uma vez que a escola alemã era um dos bens paroquiais reivindicados pelos redentoristas quando chegaram em Juiz de Fora. Para agravar a situação, em 1897, os padres holandeses decidiram que não haveria mais pregação em alemão, o que gerou a revolta dos alemães católicos e a oposição do Culto Católico, dirigida por "leigos" ${ }^{10}$ da colônia.

Frente ao exposto, é preciso considerar que as iniciativas que buscaram homogeneizar e racionalizar as práticas educativas inserem-se "nas disputas sobre os conhecimentos escolarizados e escolarizáveis", indicando "um alargamento das finalidades cada vez mais complexas imputadas à educação escolar", o que, segundo Faria Filho (1998, p. 138), foi um processo que se deu sob diversas tentativas de controle sobre os conhecimentos "autorizados" a serem ensinados na instituição escolar.

As escolas alemãs, criadas em Juiz de Fora inicialmente com a função social de educar os filhos e filhas dos imigrantes, tanto por iniciativa das famílias quanto como investimento por parte da Companhia União e Indústria, estiveram sob a administração do Culto Católico e recebiam também subvenção do Estado alemão para manutenção da instrução dos colonos ${ }^{11}$.

A vinda das irmãs de Santa Catharina para Juiz de Fora, em 1900, com o intuito de administrar as escolas paroquiais, entre elas a escola do Culto Católico, que até então assumia um caráter "leigo", acirrou a disputa pelo controle do programa de ensino entre alemães e redentoristas. No mesmo ano, os membros do Culto Católico se reuniram para organizar uma associação com o intuito de manter o "culto divino", o cemitério e as escolas regidas pelas irmãs (O PHAROL, 25 abril 1900; 08 julho 1900).

Em seu estatuto, o Culto Católico apontava dentre os fins da Associação: art. 2 § III: "Continuar a custear as escolas e mais crianças do bairro Mariano Procópio e onde possam aprender as primeiras letras, trabalhos domésticos e doutrina cristã" (ESTATUTO do Culto Católico de Mariano Procópio, 24 junho, 1900).

As escolas do Culto Católico (re)inauguradas em 15 de janeiro de 1900, no Morro da Gratidão, ficaram a cargo das irmãs de Santa Catharina, que por sua vez se submeteram a uma comissão constituída por membros da associação e chefiada por Balthasar Weiss, habitante da colônia Dom Pedro II, que até então administrava a escola.

Em 1901, um panfleto anunciava a abertura de matrícula nas escolas paroquiais, dentre as quais a escola no Morro da Gratidão e a escola diurna e noturna de São Roque da Tapera. Estas seriam administradas em colaboração entre as irmãs, a professora da escola da Tapera, a comissão organizada pelo Culto Católico e a o cura da Igreja de Nossa Senhora da Glória, o padre Adriano Wiegant, a fim de garantir a manutenção e a difusão do ensino primário no município. Contudo, no tocante à expansão do ensino leigo em Juiz de Fora, o padre redentorista investiu em discursos de reação a essas iniciativas, usando a Sociedade Propagadora do Ensino Primário como uma estratégia de controle dos programas e das práticas de ensino primário do município, bem como de centralização da administração destas escolas pela Igreja Católica:

(...) recordamos aos fiéis do Curato da Glória as seguintes palavras dos nossos Ver. Srs. Bispos nas cartas pastorais de 1901 e 1904: "Nas 
OLIVEIRA, P. R. de.

\begin{abstract}
circunstâncias em que se acha a Igreja diante do ensino leigo é de necessidade inadiável que as escolas primárias, nas quais a mocidade nascente da paróquia encontre o pasto espiritual da doutrina cristã e de outros conhecimentos uteis para a vida prática. Exoramos a todos os pais de família e tutores que enviem seus filhos e pupilos a essas escolas paroquiais. Lembramos a todos os católicos de nossas dioceses a gravíssima obrigação que têm de auxiliar a seus párocos na obra de fundar e sustentar as escolas primárias paroquiais (PANFLETO anunciando a abertura de matrículas nas escolas paroquiais, 1901).
\end{abstract}

Nessa citação podemos notar que a responsabilidade do poder local de criar escolas primárias era transferida à sociedade civil, em especial aos pais, em parceria com a Igreja, enfatizando a união para combater as escolas leigas, entre elas a escola do Culto Católico.

Frente às constantes ameaças de interferência eclesiástica, a associação buscou se fortalecer, alterando seus estatutos em 1907, sob aprovação de seus membros. Como demonstrado na notícia do jornal Minas Gerais, o bispo reagiu, determinando a dissolução da comissão do Culto Católico, porque ela não estava cumprindo a determinação de 1902 de se submeter à autoridade eclesiástica. Além disso, ele proibiu que os fiéis pagassem as prestações à comissão, já que estas deveriam ser entregues ao cura, até que uma nova comissão fosse aprovada por ele. Também restringiu a atuação das irmãs de Santa Catharina, que deveriam se encarregar somente da direção de escolas genuinamente católicas, sujeitas à autoridade eclesiástica, sendo admoestados os pais católicos que apoiassem as escolas alemãs (MINAS GERAIS, 26 julho, 1907).

Com essas medidas, a situação entre as irmãs, o cura e a presidência do Culto Católico se agravou a ponto de virar caso de polícia. Conforme noticiado no Jornal do Commercio, daquele ano, a comissão enviou uma carta às irmãs, em 10 de outubro de 1907, pedindo que elas deixassem as escolas do Culto Católico. Ao saírem, contudo, levaram tudo que eram propriedade delas, inclusive as carteiras das salas de aula. $\mathrm{O}$ presidente da Comissão dissolvida pelo arcebispo no dia anterior, chamou a polícia. Constatino Paleta, que era o advogado da Comissão e amigo do chefe de polícia, resolveu a situação, e o cura teve que recolocar todos os bens retirados da escola. $\mathrm{Na}$ mesma noite, deu-se o aviso do arrombamento das escolas e que em poucos dias as irmãs abririam suas escolas em outro lugar. Do bispo, saiu a proibição aos pais de mandarem seus filhos à escola do "Culto" (JORNAL DO COMÉRCIO, 09 outubro, 1907).

As disputas não cessaram. Em 27 de agosto de 1908, ocorreu um protesto por meio de panfletos contra o procedimento dos padres redentoristas de obrigarem as mães a retirarem seus filhos das escolas dos "ex comungados" e matriculá-las em escolas paroquiais, sob pena de excomunhão. No mês seguinte, as irmãs de Santa Catharina, que vieram às despensas do Culto Católico, foram definitivamente suspensas de suas funções na direção, visto que, após a instalação das escolas paroquiais, os alunos da Colônia haviam sido apedrejados e as professoras insultadas com o consentimento das diretoras. $\mathrm{O}$ fato acendeu ainda mais o atrito entre os alunos da escola do Culto Católico e da escola paroquial. As irmãs, depois de suspensas de suas funções, expulsaram diversas alunas das escolas, que eram filhas dos sócios da associação. Ainda assim, em 
janeiro de 1909, as aulas do Culto Católico foram instaladas e começaram a funcionar sem acompanharem as ladainhas nem as cartilhas dos padres redentoristas.

De acordo com Oliveira (2009), o programa de ensino da escola do Culto Católico previa o ensino misto destinado aos sócios, diferentemente das escolas paroquiais, onde meninos e meninas eram segregados em prédios distintos. Também havia trabalhos manuais como: crochê, lã, seda, flores e desenhos, que eram oferecidos pela professora Sofia Weiss; aulas de alemão, lecionadas por Alcide Guimarães e Francisca Grande; e aulas de português, aritmética, geografia, religião e trabalhos de agulha, ensinadas por Aida Bertorelli.

Vemos então que o ensino passou a ser ofertado por professores/as da própria colônia (civis), bem como percebe-se uma preocupação do programa em atender às exigências nacionais, sendo complementado com aspectos da cultura alemã, como a língua de origem, e os costumes (trabalhos manuais e de agulha). Esta característica sobre o ensino das escolas alemãs também foi identificada por Kreutz (2013) em relação ao processo de escolarização no sul do país.

Apesar das investidas do padre Wiegant ${ }^{12}$ em controlar o ensino nas escolas da colônia, os membros da presidência do Culto Católico - que segundo declaração da irmã Stefania, eram protestantes - resistiram, criando comissões e reivindicando judicialmente a posse dos bens doados pela Companhia União e Indústria. Como consequência, manteriam a autonomia sobre a associação, as escolas da colônia, seus professores, programas e práticas de ensino. Apesar dos esforços, os redentoristas venceram a disputa pelos bens, passando a administrá-los, definitivamente, em 1911. No mesmo ano, o Jornal do Comércio noticia a instalação de uma aula noturna em Mariano Procópio, em uma das salas do prédio onde funcionavam as aulas do Culto Católico.

No balancete da Sociedade Propagadora do Ensino Primário, datado de 25 de dezembro daquele ano, foi possível localizar o número de alunos matriculados nas aulas portuguesas e alemã-portuguesas, totalizando 230 estudantes matriculados, dentre os quais 190 eram frequentes. $E$, ao final, consta a carta pastoral daquele ano, da qual destacamos o seguinte trecho:

\footnotetext{
A educação chamada leiga, na qual não tem parte o ensino e as práticas religiosas, é a mais eficaz arma que podia inventar o inferno para ruína do cristianismo (...) enquanto a tal educação sem Deus com capa de liberdade e a título de progresso propina sorrateiramente e infiltra o veneno no coração dos moços, levandoIhes à morte espiritual e moral (...) A S. Congregação do S. Ofício conhecendo que o fim das escolas neutras ou leigas é extirpar na infância o conhecimento das verdades santas e o cuidado da religião, declarou que se devia empregar todo emprenho em persuadir aos pais de família, que nenhum mal podiam causar mais aos filhos, à pátria e ao catolicismo, do que entregar seus filhos a esta extrema desgraça (BALANCETE, 25 dezembro, 1911).
}

O arcebispo ainda afirmou: "Escolas chamadas neutras, ou ateias, são perniciosíssima invenção para arrancar do coração da infância e depois também da sociedade a fé e os sentimentos religiosos" (CARTA PASTORAL, 29 de março, 1912). ${ }^{13}$ 
OLIVEIRA, P. R. de.

As investidas contra o Culto Católico não pararam por aí. De acordo com informações do Livro de Tombo, a escola de São Geraldo fundou em 1915 uma associação própria, alegando que a Liga Católica ${ }^{14}$ não era um lugar próprio para os meninos, medida que não somente enfraquecia a associação como permitia o controle eclesiástico sobre as práticas associativas. Além disso, o número de escolas paroquiais se expandiu com a criação de mais uma escola de língua portuguesa. Em 1917, foi criada também mais uma escola paroquial com aula diurna e noturna em Manoel Honório, como reação da Seita dos Sebatistas ${ }^{15}$ (LIVRO DO TOMBO, 1917, p. 134).

A manutenção de uma escola paroquial de língua alemã denota a resistência dos colonos, que durante o período da "questão alemã" tiveram sua autonomia religiosa e econômica, além de sua liberdade de livre associação e de ensino combatidas pelo poder eclesiástico. É certo que a manutenção dos valores e da cultura perpassa pela questão da língua ${ }^{16}$, que se tornou efetivamente um problema nacional, quando, no mesmo ano, a relação do governo brasileiro com os alemães foi agravada pela declaração de guerra do presidente Venceslau Braz à Alemanha.

A partir de então o ensino da língua alemã passou a ser proibido nas escolas e também foram proibidas reuniões religiosas em alemão em todo o território nacional. Qualquer relação com as nações inimigas passou a ser motivo de perseguição, denúncia formal de espionagem ou crime de lesa-pátria. No período da Primeira Guerra Mundial, os estabelecimentos comerciais de proprietários alemães situados em Juiz de Fora, na parte central da cidade, foram apedrejados, como demonstrado nos relatos dos descendentes das famílias imigrantes do município (TRIBUNA DE MINAS, 2000).

Apesar dos entraves, não se pode desconsiderar que a secularização possibilitou que outras instituições leigas e religiosas fossem surgindo e se expandindo na cidade, podendo ser vislumbradas outras possibilidades de acesso à instrução "leiga", especialmente no nível secundário.

Ainda que a Igreja Católica tenha buscado o controle sobre o ensino primário por meio da expansão das escolas paroquiais, cujo projeto homogeneizador acabava por gerar um processo de aculturação dos filhos dos colonos, na medida em que impunha o ensino da língua portuguesa e da catequese aos fiéis, buscando retirar traços da cultura de origem, tais como a língua materna e a religião protestante; outras iniciativas despontaram, acompanhando o desenvolvimento urbano e industrial da cidade. Podemos citar: a Academia de Comércio, fundada em 1894, sob a administração dos Verbitas Alemães, e o Instituto Grambery, de orientação metodista, fundado em 1890. Ambos eram voltados para a educação de rapazes das classes médias urbanas e da elite, abrindo espaço para a continuidade dos estudos secundários e/ou comercial. Em momentos de maior intolerância dos redentoristas em relação aos alemães, em que eles foram proibidos de frequentar a Igreja do Curato de Nossa Senhora da Glória, a Congregação dos Verbitas foi responsável por recebê-los em seus cultos.

Em 1920, como demonstra Ferrenzini (2006), os embates resultaram no desgaste da associação e no enfraquecimento da devoção e das festas, que passaram para a tutela dos redentoristas. O estudo de Lisboa (2013) indica, contudo, que no ano de 1932 a escola alemã foi reorganizada, sendo assumida pela Sociedade Evangélica Escolar. Além disso, a autora indica a criação de um jardim de infância no ano de 1934, demonstrando que os estudos sobre esta escola ainda têm muito a explorar. 


\section{CONSIDERAÇÕES FINAIS}

Os estudos sobre a cultura e as práticas escolares têm demonstrado, ao longo dos anos, que estas se deram com o intuito de produzir sujeitos como um pressuposto de relações pedagógicas, estando esse processo entrelaçado à constituição de uma forma escolar. Ao observarmos atentamente as linhas aqui traçadas, veremos que para além de um projeto civilizatório moderno, encabeçado pelo Estado republicano, a fim de romper com o modelo escolar do Império, o contexto analisado teve o protagonismo da Igreja Católica na difusão de um modelo de escolarização primária notadamente hegemônico e voltado para a catequização por meio da instrução.

O modelo das escolas paroquiais nos remete ao contexto da Idade Média, como já preconizado por Martins (2019), e serviu ao processo de aculturação, desde o início da colonização, não apenas dos povos originários (os indígenas), como também das pessoas escravizadas, e porque não dizer, dos imigrantes, especialmente, após a secularização que ocorreu com o advento da República, em que a Igreja se viu pressionada a combater a expansão do ensino leigo.

Podemos perceber, contudo, que no contexto analisado a escola alemã do Culto católico representou uma reação a este modelo. Se compararmos o programa de ensino da escola alemã com o das escolas paroquiais criadas no município de Juiz de Fora, podemos notar que a modernidade pedagógica esteve mais presente nas práticas de ensino dos colonos alemães do que do projeto educativo reformador das congregações religiosas do início do século XX, o qual preconizava um ensino uniformizador, "as ladainhas", denotando uma forte influência religiosa, e a segregação das turmas e alunos segundo o sexo.

A liberdade de ensino e de associação foi reivindicada com frequência pelos colonos, como demonstraram os protestos e embates entre eles e os padres redentoristas, que vieram para o município com o objetivo de difundir e ampliar o modelo de escolarização primária paroquial. Estas disputas alavancaram diversas estratégias que se constituíram por meios associativos entre os colonos, a fim de escapar do controle eclesiástico, manter sua cultura por meio do ensino da língua de origem, da coeducação, do ensino leigo e dos trabalhos manuais. Isso porque a maioria dos membros que presidiam o Culto Católico eram de origem protestante, embora a associação agregasse alemães católicos também.

Embora não tenha sido possível precisar o número de colonos e a abrangência da escola alemã, foi possível perceber que não houve apenas uma forma de escolarização, coexistindo culturas escolares diversas que transcendem a questão civilizatória, pois perpassam questões étnicas, religiosas, econômicas, políticas, e que são construídas por sujeitos nas relações que estabeleceram e que, ao se contraporem, ajudaram a configurar a organização das escolas.

Este estudo confirmou que a manutenção das escolas pelas comunidades imigrantes foi uma prioridade na colonização alemã, em Juiz de Fora, e denuncia ainda a falta de investimento do poder público em educação primária, sendo a responsabilidade de criação das escolas frequentemente transferida para a sociedade juiz-forana, em especial para as famílias das crianças em idade escolar; bem como a manutenção das 
OLIVEIRA, P. R. de.

escolas para as associações leigas ou religiosas ou até mesmo para as próprias professoras, que tinham seus salários reduzidos conforme o número de alunos matriculados. Portanto, dar visibilidade às singularidades e regularidades das instituições, e das práticas escolares no contexto de imigração, auxilia a trazer à tona a necessidade de se investir em estudos comparativos entre as diferentes regiões do país, situando essas experiências em um contexto social e político mais amplo.

Artigo recebido em: 18/02/2021

Aprovado para publicação em: 28/05/2021

THE EDUCATIONAL PROCESS OF GERMAN IMMIGRANTS IN JUIZ DE FORA: PROJECTS IN DISPUTE BETWEEN THE 19TH AND 20TH CENTURIES

ABSTRACT: Groups of immigrants with different origins came to Brazil in the mid-19th century as a result of a governmental policy, which attracted to the municipality of Juiz de Fora: Germans, Italians, Arabs and Portuguese. The research aims to understand the impacts of immigration in the educational process and its configuration. The analysis of the Archives of the Nossa Senhora da Glória's church emphasized the German school as a place with disputes between colonists and Redemptorist priests for the control of the German school's program. Language and religion were important areas in this context.

KEYWORDS: German School. Immigration. Schooling. Childhood. Secularization.

LA ESCUELA DE INMIGRANTES ALEMANES EN JUIZ DE FORA: PROYECTOS EN DISPUTA ENTRE LOS SIGLOS XIX Y XX

RESUMEN: A mediados del siglo XIX, Brasil recibió grupos de inmigrantes de diferentes etnias a partir de una política del gobierno, que atrajo al municipio de Juiz de Fora, Minas Gerais: alemanes, italianos, árabes y portugueses. La investigación tiene como objetivo comprender los impactos de la inmigración en la organización de los procesos educativos y suya configuración. El análisis de los Archivos de la iglesia de Nossa Senhora da Glória dio foco a la escuela alemana, demostrando disputas entre los colonos y los sacerdotes redentoristas por el control del programa de la escuela alemana. Las disputas tienen que ver con el tema de la enseñanza del idioma y la religión de origen.

PALABRAS CLAVE: Escuela alemana. Inmigración. Enseñanza. Infancia. Secularización.

Inter-Ação, Goiânia, v.46, n.2, p. 464-481, maio/ago. 2021. Disponível em: <http://dx.doi.org/10.5216/ia.v46i2.67782>. 


\section{NOTAS}

1 - Cabe destacar que, neste período, a Alemanha não era um Estado unificado, o que só ocorreu oficialmente em 1871, desse modo, há uma preocupação em não generalizar o uso do termo alemão, antes desta data. Os ideais de unificação fortaleceram-se com o crescimento dos movimentos nacionalistas, a partir de 1848, e as guerras de unificação que foram conduzidas pelos prussianos sobre os ducados controlados pela Dinamarca e, posteriormente, sobre as forças austríacas e francesas (MAGALHÃES, 2019).

2 - Os contratos eram assinados antes do embarque para o Brasil. Como a religião do Império era a Católica, os protestantes, após o casamento, ainda eram obrigados a assinar um termo abrindo mão de sua prática religiosa no país.

3 - Nasceu em Barbacena-MG. Filho de José Ferreira Armond e da Baronesa de Sant'Ana. Além de ser o engenheiro responsável pela construção da companhia e da estrada de mesmo nome, durante 1856 e 1861, foi também deputado provincial e representante da província de Minas Gerais, entre os anos de 1861 a 1864 e 1869 a 1872. Foi ainda responsável pela fundação da primeira usina hidrelétrica da América Latina, localizada no município de Juiz de Fora. A Vila Ferreira Lage deu origem a um dos mais significativos acervos do país, sendo transformado no primeiro museu do estado de Minas, em 1915, e doado em 1936 para o município, hoje conhecido como Museu Mariano Procópio (OLIVEIRA, 2016, p. 16-18).

4 - Mais informações disponíveis em: Os alemães em Juiz de Fora | almanaquejuizdefora (almanaquehistoriajuizfora.com). Acesso em: 28 mai. 2021.

5 - Não há um consenso nas fontes sobre o número exato de imigrantes. Martins (2019) apresenta uma análise da população com base nos dados da obra de Stehling (1979), que é de 1162, no ano de 1858. Esse número difere do quantitativo apresentado pela publicação do Jornal Tribuna de Minas de 2000, que é de 1193.

6 - Este termo utilizado para designar a associação civil organizada no município pelos alemães que vieram trabalhar na Cia. União Indústria aparece na publicação especial do Jornal Tribuna de Minas do ano 2000, contudo, nas fontes do acervo da Paróquia de Nossa Senhora da Glória, o termo utilizado pelos atores da época para designar essa associação era "Culto Católico" que, segundo Stehling (1979), foi criado em 1879. Outra informação que diverge sobre o uso do termo pode ser constatada em Martins (2019), que usa os termos "Culto Católico" e "Culto Evangélico", a fim de distinguir a organização de alemães católicos e a de luteranos. Contudo, esta distinção não aparece na documentação. O "Culto Católico" era considerado pelos padres redentoristas uma associação leiga, presidida por colonos luteranos. A fim de evitar anacronismo, manteremos ao longo do texto apenas a denominação "Culto Católico", que foi a utilizada nas fontes documentais, em especial nas anotações do livro paroquial. Gasparetto Junior (2011), por sua vez, faz menção à história da "Sociedade Alemã de Beneficência", criada em 1872, pelos imigrantes alemães, italianos e portugueses, contudo a documentação analisada também não faz menção a essa sociedade mútua, não sendo possível concluir se está se referindo à mesma associação.

7 - Na obra de Neto (2006), podemos encontrar detalhes sobre as missões dos redentoristas em Juiz de Fora, bem como relatos dos padres sobre suas ações. Eles iniciaram as visitas e pregações nos bairros Grama, São Pedro e Benfica, localidades em que estavam situadas as colônias alemães. As pregações, a princípio, eram em português e alemão. Contudo, como constatado na documentação, os embates entre redentoristas e alemães se acentuaram quando aqueles passaram a proibir o ensino na escola da colônia e as pregações na língua alemã, no início do século XX.

8 - Eram então membros da Comissão do Culto Católico: José Weiss (presidente), Adolfo Larcher (secretário) Pedro José Hansen (procurador), Felipe Dilly (tesoureiro), Teodoro Frank (vice), Jacó Antônio de Abreu e Francisco Pedro Kremer (sócios). 
OLIVEIRA, P. R. de.

9 - Ferrenzini (2006) aponta em seu artigo a reforma e a normatização proposta pelos redentoristas holandeses em Juiz de Fora, desvelando o caráter rígido e autoritário de suas ações no município a partir de 1894.

10 - Na documentação percebe-se que os padres católicos redentoristas não faziam distinção entre "leigos" e demais denominações religiosas que não fossem a católica.

11 - O investimento por parte da companhia União Indústria em escola é questionável quando, na obra de Stehling (1979), se tem acesso às denúncias feitas pelos colonos, por meio de cartas enviadas aos seus países de origem, relatando as más condições em que viviam, a exploração do trabalho pela companhia que chegava a 10 horas diárias e a retenção de $50 \%$ do valor do pagamento em função de dívidas que se acumulavam. Efetivamente, a escola foi doada aos colonos somente em 1885.

12 - O período correspondente, entre 20 de março de 1907 e 09 de dezembro de 1909, foi considerado o auge da luta pela "questão alemã", quando o padre Adriano Wiegant substituiu seu antecessor o padre Augusto Bekers.

13 - Até então eram mantidas três escolas paroquiais denominadas de "portuguesas" e apenas uma escola alemã (possivelmente, a escola da Colônia).

14 - Em 1915, o termo Liga Católica aparece na documentação para se referir à associação do Culto Católico.

15 - Não localizamos mais informações sobre esta seita nas fontes e nem na bibliografia.

16 - Não se pode descartar neste processo a possível influência do pangermanismo, cuja ação esteve presente no sul do país e é tratada nos estudos de Magalhães (1998). A autora analisa como os militantes nacionalistas estabeleceram, por meio de discursos religiosos e de suas relações cotidianas nas comunidades alemãs, o pangermanismo e os ideais nazistas. Tal relação pode estabelecer maior dinâmica aos embates, contudo não encontramos nas fontes elementos que comprovem esta influência no contexto mineiro.

\section{REFERÊNCIAS BIBLIOGRÁFICAS}

AZZI, Riolando. Sob o básculo episcopal: a Igreja católica em Juiz de Fora (1850-1950). Juiz de Fora: Templo, 2000.

CARTA PASTORAL. 29 março, 1912.

CARVALHO, Carlos Henrique de. A história local e regional: dimensões possíveis para os estudos histórico-educacionais. In: Cadernos de História da Educação. n. 6, jan.-dez., 2007.

CONTRATO de funcionamento para a escola de São José. 20 julho, 1928.

COSTA, Fernanda Maria M. A morte e o morrer em Juiz de Fora: transformações nos costumes fúnebres (1851-1890). Dissertação (Mestrado em História). Universidade Federal de Juiz de Fora, Juiz de Fora. 2007.

ESTATUTO do Culto Católico de Mariano Procópio. 24 junho, 1900. 
FARIA FILHO, Luciano Mendes. Escolarização e cultura escolar. História da Educação em debate. Ilhéus: UESC, $2020 . \quad$ Disponível em: https://www.youtube.com/watch?v=fHHz9l8-GbM. Acesso em: 18 fev. 2021.

FARIA FILHO, Luciano Mendes de. Cultura e prática escolares: escrita, aluno e corporeidade. Cad. Pesq., v. 1, n. 103, p. 136-149, mar. 1998.

FERRENZINI, Valéria Leão. Reforma e normatização: os redentoristas holandeses em Juiz de Fora. In: Anais do XII Encontro Regional de História. Anpuh Rio, 2006.

GASPARETTO JUNIOR, Antonio. Mutualismo alemão em Juiz de Fora: o reforço da identidade em perspectiva. Contemporâneos: revista de artes e humanidades. n. 8, mai/out, p.1-14, 2011.

IOTI, Luiza Horn. A política imigratória brasileira e sua legislação (1822-1914). In: Anais do X Encontro Estadual de História. UFSM. Santa Maria, RS, 2010. p. 1-17.

JORNAL DO COMÉRCIO, 09 outubro, 1907.

KREUTZ, Lúcio. Escolas étnicas da imigração alemã no Rio Grande do Sul. In: Anais do XI Educere. Puc Paraná. Curitiba, 2013.

LISBOA, Jakeline Duque de Moraes. A escola alemã em Juiz de Fora (1860-1935). Instrumento: R. Est. Pesq. Educ. Juiz de Fora, v. 15, n. 1, jan-jun, 2013. p. 75-80.

LIVRO DE TOMBO. Juiz de Fora. 1885, p. 8.

MAGALDI, Ana Maria Bandeira de Melo; XAVIER, Libânia Nacif. Impressos e história da educação: usos e destinos. Rio de janeiro: 7 letras, 2008. p. 9-14.

MAGALHÃES, Ana Paula Tavares. A historiografia alemã do século XIX: política e poder na construção do "mito da nação". Revista Ágora. Vitória. n. 30, p. 192-208. 2019.

MAGALHÃES, Marionilde Brepohl de. Pangermanismo e nazismo: a trajetória alemã rumo ao Brasil. São Paulo: Editora da UNICAMP/FAPESP, 1998. 258 p.

MARTINS, Marco Aurélio Corrêa. A caridade na ausência da cidadania: escolarização católica gratuita de crianças pobres no Rio de Janeiro na transição Império - República. Inter-ação. v. 44 , n. 2 , 2019.

MARTINS, Marco Aurélio Corrêa. As escolas da Colônia de D. Pedro Il em Juiz de Fora e o acesso à educação primária na transição do Império para a República. ROCHA, Marlos Bessa Mendes da. A longa constituição da modernidade educacional brasileira. Curitiba: CRV, 2019. 
OLIVEIRA, P. R. de.

MINAS GERAIS, 26 julho, 1907.

NETO, Luciano Dutra. Das terras baixas da Holanda às montanhas de Minas: uma contribuição à história das missões redentoristas, durante os primeiros trinta anos de trabalho em Minas Gerais. Doutorado. Programa de Pós-graduação em Ciência da Religião. Juiz de Fora: UFJF, 2006. p. 100-112.

O PHAROL. Juiz de Fora, 25 abril, 1900.

O PHAROL. Juiz de Fora, 08 julho, 1900.

OLIVEIRA. Paloma Rezende de. A história da Estrada União e Indústria. OLIVEIRA, Paloma Rezende de. FÁVERO, Cristina Hill, MENDONÇA, Mônica C.C. União e Indústria: sua contribuição para a construção de Juiz de Fora. Juiz de Fora: Templo, 2016.

OLIVEIRA. Paloma Rezende de. Criança: "futuro da nação", "célula do vício": políticas de assistência à infância em Juiz de Fora/MG na transição do Império para a República. Dissertação (Mestrado em Educação). UFJF, Juiz de Fora, 2009.

OLIVEIRA. Paloma Rezende de. Vinde a mim os pequeninos: políticas de assistência à infância em Juiz de Fora na transição do Império para a República. Funalfa: Juiz de Fora, 2012.

PANFLETO anunciando a abertura de matrículas nas escolas paroquiais. Juiz de Fora, 1901.

RENK, Valquiria Elita e MASCHIO, Elaine Cátia Falcade. Por uma história da escola primária no contexto de imigração: experiências de escolarização entre imigrantes eslavos e peninsulares itálicos no Paraná. Revista Brasileira de História da Educação. v. 20, n. 1, 2020.

SANTOS, Ademir Valdir dos. Educação e colonização no Brasil: as escolas étnicas alemãs. Cad. Pesquisa. v. 42, n. 146. São Paulo. May/Aug. 2012.

SEYFERTH, Giralda. A dimensão cultural da imigração. RBCS. v. 26, n. 77, out., p. 47-62, 2011.

STEHLING, Luiz José. Juiz de Fora: a Companhia União e Indústria e os alemães. Juiz de Fora: Funalfa, 1979.

STEPHAN, Luiz Antonio. Almanaque História de Juiz de Fora. Disponível em: https://www.almanaquehistoriajuizfora.com/os-alemaes-em-juiz-de-fora. Acesso em: 28 mai. 2021.

Inter-Ação, Goiânia, v.46, n.2, p. 464-481, maio/ago. 2021. Disponível em: <http://dx.doi.org/10.5216/ia.v46i2.67782>. 
TRIBUNA DE MINAS. Imigrantes: 150 anos. Edição comemorativa dos 150 anos de Juiz de Fora. Juiz de Fora, 31 mai. 2000.

Paloma Rezende de Oliveira: Professora na Universidade do Estado de Minas Gerais Unidade Carangola. Pós-doutorado em Educação realizado no Programa de Pósgraduação em Educação da Unirio (2018). Doutorado em Ciências Humanas e Educação pela PUC-Rio (2016). Mestre em Educação pela Universidade Federal de Juiz de Fora (2009).

Orcid: https://orcid.org/0000-0002-0263-8126

E-mail: paloma.oliveira@uemg.br

Este periódico utiliza a licença Creative Commons Attribution 3.0, para periódicos de acesso aberto (Open Archives Initiative - OAI). 